\title{
An evaluation of the heat precipitation method for plasma fibrinogen estimation
}

\author{
H. R. MillaR, J. G. SIMPSON, AND A. L. STALKER \\ From the Department of Pathology, University of Aberdeen
}

SYNOPSIS A rapid heat precipitation micromethod for the estimation of plasma fibrinogen is described. Its validity and reproducibility have been extensively tested. The method correlates well with a more generally used thrombin-clotting technique over a wide range of fibrinogen levels.

The methods available for the assay of plasma fibrinogen depend on its coagulability by thrombin, its behaviour on salt-fractionation, its antigenicity, its electrophoretic mobility, or its heat precipitability. They all contain important sources of possible error (Huseby and Bang, 1971). The most generally accepted techniques are based on the estimation of fibrinogen as fibrin after thrombin conversion; they are, however, time-consuming and unsuitable for rapid estimations on large numbers of samples. The method most easily adopted as a simple, rapid screening measure is the heat precipitation technique.

Fredericq in 1877 first demonstrated that a plasma component essential for clotting was precipitated at $56^{\circ} \mathrm{C}$. Methods for the quantification of this heatprecipitated fraction, which is the plasma fibrinogen, have been described by Schulz (1955), Goodwin (1965), and Low, Hill, and Searcy (1967). The technique is not in general use presumably because of doubts as to its validity and reproducibility; these have been investigated in the present study by a rapid heat precipitation micromethod, based on that described by Low et al (1967).

\section{Methods}

THE HEAT PRECIPITATION TECHNIQUE

Venous blood is collected into sequestrene and drawn into two microhaematocrit capillary tubes. These are sealed at one end by heat and spun in a Hawksley microhaematocrit centrifuge $(12,000 \times g)$ for five minutes. The tubes are placed for three minutes in a waterbath at $56^{\circ} \mathrm{C}\left( \pm 1^{\circ} \mathrm{C}\right)$, care being taken to ensure that the plasma columns are entirely under the water surface. The plasma becomes opaque due to precipitation of the fibrinogen which is then packed on top of the buffy coat by centrifugation Received for publication 28 July 1971. for a further three minutes. The capillary tubes are placed on a movable microscope stage fitted with a vernier and viewed by transmitted light at a magnification of $\times 24$. The focusing eyepiece contains a hair line. The length of the column of precipitate is measured in relation to that of the original plasma column (Fig. 1): readings are made to the nearest $0.1 \mathrm{~mm}$ on the vernier. The amount of fibrinogen in the plasma is then $A B / A C \times 100=\mathrm{ml} / 100 \mathrm{ml}$. The mean of the readings in the two tubes is taken.

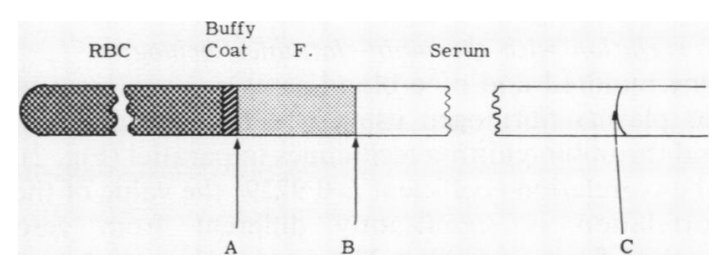

Fig. 1 Diagrammatic representation of the capillary tube contents after the heat precipitation and centrifugation of fibrinogen, showing packed fibrinogen $F$, buffy coat/fibrinogen interface A, fibrinogen/serum interface $B$ and serum meniscus $\mathrm{C}$.

THROMBIN-CLOTTABLE FIBRINOGEN

The method employed was that of Ogston and Ogston (1966), which is a modification of that of Ratnoff and Menzie (1951). The fibrin formed by the action of thrombin on fibrinogen is hydrolysed by boiling alkali and its tyrosine content measured with Folin-Ciocalteu's phenol reagent.

PREPARATION OF FIBRINOGEN DEGRADATION PRODUCTS (FDP)

Five hundred Ploug units of urokinase (Leo) were added to $25 \mathrm{ml}$ of a $0.4 \%$ solution of human fibrinogen (Kabi). The mixture was incubated at $37^{\circ} \mathrm{C}$ for 
30 minutes at which time $1.9 \mathrm{ml}$ of a $2000 \mathrm{KIU} / \mathrm{ml}$ solution of Trasylol (Bayer) was added to prevent further proteolysis. Undigested fibrinogen was clotted by thrombin and removed by centrifugation.

\section{MEASUREMENT OF FIBRINOGEN DEGRADATION} PRODUCTS

The method used was the tanned red cell haemagglutination inhibition (TRCHI) technique using the Wellcome kit. It was not possible to remove completely heterophile antibodies despite repeated absorption with sheep red cells: this method would thus be unreliable for the detection of low levels of fibrinogen degradation products.

\section{IMMUNODIFFUSION}

This was performed after the method of Mansi (1958) using rabbit antisera (Behringwerke) to a wide variety of human plasma proteins.

\section{Results}

\section{VALIDITY OF THE METHOD}

Addition of fibrinogen to saline, serum, and plasma Known incremental amounts of fibrinogen were added to volumes of saline, serum, and plasma and the heat precipitation test was performed. In every instance the predicted fibrinogen level was observed.

\section{Correlation with thrombin-clottable fibrinogen}

One hundred and nine blood samples were assayed for plasma fibrinogen using the heat-precipitation and thrombin-clotting techniques in parallel (Fig. 2). The correlation coefficient is 0.9729 : the value of the correlation is significantly different from zero $(t=13.83, P<0.001)$. The regression equation of the heat precipitation method on the thrombinclotting method is $x=2.5771+0.9871(y-3.1415)$, when $x$ is the heat precipitate value for a given value, $y$, of the clotting method. It might have been expected that the regression line would pass through the origin $(x=y=0)$ but the intercept on the $y$ axis is 0.53 . This suggests that either the heat precipitation method underestimates or the clotting method overestimates the true value by a small fixed quantity. The graph could, of course, be used for the conversion of heat precipitate values to the more standard $\mathrm{mg} / 100 \mathrm{ml}$ unit.

A similar study on 23 rabbit blood samples again gave good correlation between the two methods although a statistical analysis has not been made.

Effect of FDP on the heat precipitation method The FDP preparation had a high total concentration of $5,000 \mu \mathrm{g} / \mathrm{ml}$ as tested by the TRCHI technique.

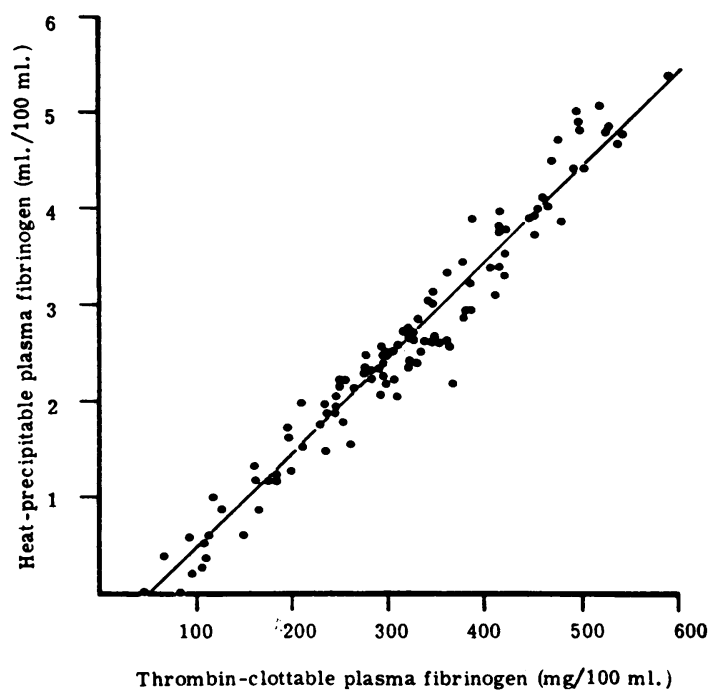

Fig. 2 Correlation between heat-precipitation and thrombin-clottable methods for fibrinogen estimation.

Eighty per cent of this FDP preparation was precipitable at $56^{\circ} \mathrm{C}$, giving a value of $1 \mathrm{ml} / 100 \mathrm{ml}$ : the supernatant comprised fragment $\mathrm{E}$ which is not precipitated at this temperature. Theoretically, to give a notably false reading, a concentration of at least $1,000 \mu \mathrm{g} / \mathrm{ml}(0.2 \mathrm{ml} / 100 \mathrm{ml})$ total FDP would have to be present in the plasma under test. To test this, incremental amounts of FDP were added to normal plasma: only at levels of $1,000 \mu \mathrm{g} / \mathrm{ml}$ or higher was there an increase in the resultant precipitate outside a $10 \%$ allowable limit. Fibrinogen degradation products did not prevent the heat precipitation of fibrinogen itself, although they may interfere with its conversion to fibrin in a thrombin-clotting technique (Hirsh, Fletcher, and Sherry, 1965).

\section{Effect of heating on other plasma proteins}

Immunodiffusion showed that no fibrinogen remained in the supernatant after heat precipitation and centrifugation. Electrophoresis showed that no other normal plasma protein was significantly altered, either quantitatively or electrically, by heating to this temperature.

\section{REPRODUCIBILITY OF THE METHOD}

\section{Type of anticoagulant}

Blood samples were collected in various standard anticoagulants, namely, sequestrene, ammonium potassium oxalate, sodium citrate, and heparin. No significant difference was noted in the fibrinogen values obtained. Sequestrene anticoagulation, how- 
ever, was found to give the most distinct interface between the buffy coat and the heat precipitate and is regarded as the anticoagulant of choice.

\section{Storage of blood}

Storage of blood overnight at $4^{\circ} \mathrm{C}$ made no difference to the estimations. Freezing of plasma alone and storage at $-20^{\circ} \mathrm{C}$ for up to one month similarly had no effect, although repeated freezing and thawing did produce inconsistent results.

\section{Duration of heating and centrifugation}

Five minutes' initial centrifugation, three minutes' heating, and three minutes' recentrifugation were found to be optimal. Shorter times gave inconsistent results, while prolongation of any step to 15 minutes did not alter the results.

\section{Temperature}

There was no variation in results within a temperature range of 55 to $57^{\circ} \mathrm{C}$.

\section{Observer variation and test-retest difference}

A theoretical source of observer error is precise localization of the interfaces (lines A and B in Fig. 1). The buffy coat is pale brown compared with the white homogeneous layer of packed fibrinogen. Occasionally lines A and B are not strictly at right angles to the tube wall and the 'line of best fit' has to be chosen. If, as rarely happens, the interfaces are extremely irregular, the test is repeated. Precise vernier reading is essential.

From 70 blood samples two separate aliquots were taken and on each of these two fibrinogen estimations were made. The mean difference was $0 \cdot 124 \mathrm{ml} / 100 \mathrm{ml}(\mathrm{SD} \pm 0 \cdot 114)$. Ninety-three per cent of the estimations had a test-retest difference of less than $0.3 \mathrm{ml} / 100 \mathrm{ml}$. Any test showing a difference between the two tubes of more than $0.3 \mathrm{ml} / 100 \mathrm{ml}$ should therefore be repeated: this difference is equivalent to $30 \mathrm{mg} / 100 \mathrm{ml}$, ie, about $10 \%$ in the normal plasma fibrinogen range.

\section{Discussion}

This heat precipitation method for plasma fibrinogen measurement requires little technical skill, apart from precise vernier reading, and no chemical reagents. The equipment used is simple and available in many siderooms: in the absence of a water bath, a simple tap-water bath is adequate. One sample can be assayed in 15 minutes, a dozen in half an hour. The method correlates well with a more generally used thrombin-clotting technique over a wide range of fibrinogen levels.

We have confirmed the results of Beller and Maki
(1967) that FDPs do not prevent the heat precipitation of fibrinogen. Certain FDPs are themselves heat precipitable and a false high value may be obtained if they are present in very high concentration. Some of these FDPs are also incorporated into the clot (Alkjaersig, Fletcher, and Sherry, 1962) so that the simultaneous heating of plasma and serum samples will not give an accurate estimation of the proportion of FDP in the plasma precipitate. As we have shown, however, FDP concentrations in plasma must exceed $1,000 \mu \mathrm{g} / \mathrm{ml}$ before the reading is increased outside the limits of error of the method: such levels are rare, even in defibrination secondary to severe obstetric haemorrhage (Bonnar, Davidson, Pidgeon, McNicol, and Douglas, 1969).

Variable results have been noted in the heat precipitability of fibrinogen in jaundice (Foster, DeNatale and Dotti, 1959) and rare abnormal plasma proteins may be precipitated at $56^{\circ} \mathrm{C}$ (Collier, Reich, and King, 1951) but will also be precipitated in heated serum.

The heat precipitation method seems particularly suitable as a screening technique. We have used it in a serial study of fibrinogen levels in over a thousand pregnant women, and in several instances where defibrination occurred the results correlated well with those obtained by the thrombin-clotting method.

Part of this work was supported by a grant to H.R.M. from the Wellcome Foundation. We are grateful to Dr David Hall for statistical analyses, Dr F. AllertRecht for electrophoretic studies, Professor A. S. Douglas for helpful comment and criticism, and Professor A. R. Currie for his continued interest and support.

\section{References}

Alkjaersig, N., Fletcher, A. P., and Sherry, S. (1962). Pathogenesis of the coagulation defect developing during pathological plasma proteolytic ('fibrinolytic') states. II. The significance, mechanism and consequences of defective fibrin polymerization. J. clin. Invest., 41, 917-934.

Beller, F. K., and Maki, M. (1967). Properties of fibrinogenolysis and fibrinjlysis products in immune assays. Thrombos. Diathes. haemorrh. (Stuttg.), 18, 114-132.

Bonnar, J., Davidson, J. F., Pidgeon, C. F., McNicol, G. P., and Douglas, A. S. (1969). Fibrin degradation products in normal and abnormal pregnancy and parturition. Brit. med. J., 3, 137-140.

Collier, F. C., Reich, A., and King, J. W. (1951). Multiple myeloma. New Engl. J. Med., 245, 969-971.

Foster, J. B. T., DeNatale, A., and Dotti, L. B. (1959). Determination of plasma fibrinogen by means of centrifugation after heating. Amer. J. clin. Path., 31, 42-45.

Fredericq, L. (1877). De l'existence dans le plasma sanguin d'une substance albuminoide se coagulant a +56 degrés centigrades. Arch. Zool. exp. gén., 6, XIV-XVI.

Goodwin, J. F. (1965). An evaluation of technics for the separation and estimation of plasma fibrinogen. Clin. Chem., 11, 63-73.

Hirsh, J., Fletcher, A. P., and Sherry, S. (1965). Effect of fibrin and fibrinogen proteolysis products on clot physical properties. Amer. J. Physiol., 209, 415-424. 
Huseby, R. M., and Bang, N. U. (1971). Fibrinogen. In Thrombosis and Bleeding Disorders, edited by N. U. Bang, F. K. Beller, E. Deutsch, and E. F. Mammen, pp. 222-247. Academic Press, London and New York.

Low, E. M. Y., Hill, H. B., and Searcy, R. L. (1967). Simple method for detection of abnormal plasma fibrinogen levels. Amer. $J$. clin. Path., 47, 538-540.

Mansi, W. (1958). Slide gel diffusion precipitin test. Nature (Lond.), 181, 12891290.
Ogston, C. M., and Ogston, D. (1966). Plasma fibrinogen and plas- $\stackrel{?}{?}$ minogen levels in health and ischaemic heart disease. J. clin. Path., 19, 352-356.

Ratnoff, O. D., and Menzie, C. (1951). A new method for the deter- $\mathcal{C}$ mination of fibrinogen in small samples of plasma. J. Lab. 음 clin. Med., 37, 316-320.

Schulz, F. H. (1955). Eine einfache Bewertungsmethode von Leber- $\frac{\bar{\sigma}}{\bar{T}}$ parenchymschäden (volumetrische Fibrinestimmung). Acta $\frac{\sigma}{7}$ hepat. (Hamburg), 3, 306-313.

\section{The November 1971 Issue}

\section{THE NOVEMBER 1971 ISSUE CONTAINS THE FOLLOWING PAPERS}

Electron microscope study of PNH red cells and AET-treated normal red cells (PNH-like cells) s. $\mathrm{M}$. LEWIS, G. LAMBERTENGHI, S. FERRONE, AND G. SIRCHIA

The long-term storage of blood for transfusion using an improved container for freezing the red cells in liquid nitrogen W. J. JENKINS AND J. BLAGDON

Stability of prothrombin and factor VII in freezedried plasma M. BROZOVIĆ, L. J. GURD, I. ROBERTSON, AND D. R. BANGHAM

Ascorbic acid status in iron-deficiency anaemia A. JACOBS, D. GREENMAN, E. OWEN, AND I. CAVILL

Vitamin $\mathbf{B}_{\mathbf{1 2}}$ levels in erythrocytes in hypochromic anaemia R. J. HARRISON

Quality control in routine haemoglobinometry $\mathrm{I}$. CAVILL

The effect of oxygen on the fibrinolytic enzyme system in vivo G. M. CUNNINGHAM, G. BOYD, J. WINDEBANK, F. MORAN, AND G. P. MCNICOL

The effect of $p \mathrm{H}$ on the multiplication of a pseudomonad in chlorhexidine and cetrimide D. C. J. BASSETT

Bacteriocine typing of Klebsiella spp FELICITY A. HALL

Quantitative studies on the salivary flora P. W. ROSS

The effect on sepsis rates of closing and cleaning hospital wards PAUL NOONE AND ROSE J. GRIFFITHS

The distribution of plasminogen activator in the male genital tract R. C. KESTER
Multiple immunological abnormalities in a family AIASTAIR M. S. MASON AND PETER L. GOLDING

Sudden unexplained death in infancy and hyperimmunization G. E. D. URQUHART, R. W. LOGAN, AND M. M. IZATT

Standardization of clinical enzyme assays D. W. MOSS, D. N. BARON, P. G. WALKER, AND J. H. WILKINSON

Malignant lymphoma of parotid associated with Mikulicz disease (benign lymphoepithelial lesion) J. G. AZZOPARDI AND D. J. EVANS

Fat-laden macrophages in cerebrospinal fluid as an indication of brain damage in children D. C. CHESTER, J. L. EMERY, AND S. R. PENNY

\section{Technical methods}

A carbon-dioxide-in-air incubator M. W. SCRUTON

An inexpensive and demountable walk-in incubator용 R. N. P. SUTTON AND G. AYLETT

A simple device for counting Jerne's plates to detect haemolytic antibody-forming cells G. PETRACCHI, M. BENDINELLI, AND G. FALCONE

\section{Present day practice}

Conditions for the estimation of serum lactic dehydrogenase activity using the LKB 3600 reaction $N$ rate analyser and the range found in healthy subjects R. W. RICHARDSON AND C. P. PRICE

The Association of Clinical Pathologists: 87th general meeting

Letter to the Editor

Book reviews

Copies are still available and may be obtained from the PUBLISHING MANAGER, BRITISH MEDICAL ASSOCIATION, TAVISTOCK SQUARE, LONDON, WC1H 9JR, price, 105p. 